\title{
The Importance of Equilibration Time to Glycerol Prior to Freezing in the Cryopreservation of Mouse Embryos
}

\author{
Hajime Miyamoto, Yohei Miyamoto and Takehiko Ishibashi \\ Department of Animal Science, Faculty of Agriculture, \\ Kyoto University, Kyoto-shi 606
}

(Received July 12, 1985)

\begin{abstract}
A controversial question in low temperature preservation of mammalian embryos is whether a cryoprotective agent must permeate embryos to protect them against freezing damage. The present study has been designed to examine the effect of exposure time to glycerol prior to freezing on the survival of mouse embryos frozen rapidly and also to examine the effect of embryonic stages on the survival of embryos frozen with several methods. Glycerol was added to morulae at $0^{\circ} \mathrm{C}$, and after being exposed to glycerol at $0^{\circ} \mathrm{C}$ for various periods, they were frozen by placing directly from $0^{\circ} \mathrm{C}$ to liquid nitrogen vapor at $-170 \sim-180^{\circ} \mathrm{C}$ or to a $-40^{\circ} \mathrm{C}$ bath before transfer to liquid nitrogen. No embryos survived when they were exposed to $2 \mathrm{M}$ glycerol at $0^{\circ} \mathrm{C}$ for $0.1 \mathrm{~min}$. The highest survival rates were obtained when the embryos were exposed for $5 \sim 30 \mathrm{~min}$ in the former freezing method and were exposed for $20 \sim 30 \mathrm{~min}$ in the latter method. If slow freezing methods were used, 8-cell stage embryos, morulae and early blastocysts survived better than the other embryonic stages. If rapid freezing methods were used, morulae and early blastocysts survived better than the other stages, suggesting their low susceptibility to the freezing and thawing procedures. The present results suggest that the increase in glycerol permeation of mouse embryos enhances their survival, although it is not the sole factor which determines the survival of frozen embryos.
\end{abstract}

Jpn. J. Zootech. Sci., 57 (3): 250-256, 1986

Key words: glycerol, equilibration time, rapid freezing, mouse embryos

The survival of mammalian embryos frozen to low temperatures requires the presence of protective agents such as dimethyl sulphoxide (DMSO) or glycerol. The actual mechanisms by which these agents protect embryos against freezing damage remain obscure. A fundamental question is whether an agent that protects embryos against freezing damage must permeate them to exert its beneficial effect.

The cryoprotective agents used for embryo freezing are able to penetrate cells and the extent of permeation required for protection is reflected to some extent by the temperature and duration of exposure to agents before freezing "). The rate of glycerol permeation will be also influenced by differences in the permeability characteristics of embryos at various stages of development. There is an increase in the rate of glycerol permeation of fertilized mouse ova compared to that of unfertilized ova ${ }^{2}$. Further development of the mouse zygote, through the preimplantation stages to blastocyst, is accompanied by a further large increase in the rate of glycerol permeation ${ }^{\mathbf{3} 4)}$. Most workers have exposed embryos to protective agents for about 10-20 min before 
freezing of the embryos ${ }^{1)}$. It is, however, suggested that DMSO and glycerol need not permeate mouse embryos to protect them against freezing damage ${ }^{5,6}$.

The purposes of this paper are to examine the survival of mouse embryos frozen rapidly after being exposed to glycerol for various periods and also to examine the survival of mouse embryos at various stages of development after freezing.

\section{Materials and Methods}

ICR female mice ( $4 \sim 6$ weeks of age) were superovulated by intraperitoneal injections of $10 \sim 15$ i. u. of PMSG and HCG given $48 \mathrm{hr}$ apart and then were mated. The embryos (2-cell, 4-cell, 8-cell, morula, early blastocyst and blastocyst) were recovered from the reproductive tracts with modified phosphate-buffered salt solution $(\mathrm{PBS})^{7)}$ and $10 \sim 25$ embryos were transferred to each glass test-tube containing 0.1 $\mathrm{ml}$ PBS. The tubes were cooled to $0^{\circ} \mathrm{C}$ at $2^{\circ} \mathrm{C} / \mathrm{min}$ in an ethanol bath. Glycerol in $0.15 \mathrm{~m} l$ PBS was added to samples at $0^{\circ} \mathrm{C}$ by the single addition or glycerol in PBS was added to samples in two increments of $0.075 \mathrm{ml}$ at $10-\mathrm{min}$ intervals. The final concentration of glycerol was $1.5 \mathrm{M}$ for slow freezing and $2 \mathrm{M}$ for rapid freezing method. To determine whether the exposure time of embryos to glycerol at $0^{\circ} \mathrm{C}$ prior to freezing has any effect on the survival of frozen-thawed embryos, the embryos were kept in glycerol at $0^{\circ} \mathrm{C}$ for $0.1 \sim 60 \mathrm{~min}$ after the single addition of glycerol. Then, they were frozen rapidly to $-196^{\circ} \mathrm{C}$ without or after ice-seeding. To examine the effects of embryonic stages on the survival of embryos frozen, the embryos at different stages were kept in glycerol at $0^{\circ} \mathrm{C}$ for $10 \mathrm{~min}$ after the final addition of glycerol.

The samples were frozen to $-196^{\circ} \mathrm{C}$ by one of the following ways. Freezing methods $\mathrm{A}$ and $\mathrm{B}$ are slow or modified slow freezing, and methods $\mathrm{C}, \mathrm{D}, \mathrm{E}$ and $\mathrm{F}$ are two-step rapid freezing. (A) The samples were cooled at $0.5^{\circ} \mathrm{C} / \mathrm{min}$ to $-75^{\circ} \mathrm{C}$ before transfer to liquid nitrogen. (B) The samples were cooled at $0.5^{\circ} \mathrm{C} / \mathrm{min}$ to $-40^{\circ} \mathrm{C}$ before transfer to liquid nitrogen. (C) The samples were placed directly into a $-20^{\circ} \mathrm{C}$ bath for $20 \mathrm{~min}$ before transfer to liquid nitrogen. (D) The samples were placed directly into crushed dry ice for $15 \mathrm{~min}$ before transfer to liquid nitrogen.

The samples were cooled to $-7^{\circ} \mathrm{C}$ at $1^{\circ} \mathrm{C} / \mathrm{min}$, ice-seeded and held for $5 \mathrm{~min}$ at this temperature. They were then frozen rapidly by placing them from $-7^{\circ} \mathrm{C}$ to liquid nitrogen vapor at $-170 \sim-180^{\circ} \mathrm{C}$ and then to liquid nitrogen 15 min later. (F) The samples were frozen rapidly by placing them from $0^{\circ} \mathrm{C}$ to liquid nitrogen vapor at $-170 \sim-180^{\circ} \mathrm{C}$ without ice-seeding and then to liquid nitrogen $15 \mathrm{~min}$ later.

The samples were thawed slowly $\left(20^{\circ} \mathrm{C} / \mathrm{min}\right)$ in air at room temperature or rapidly $\left(500^{\circ} \mathrm{C} / \mathrm{min}\right)$ by agitating them in a $40^{\circ} \mathrm{C}$ water bath. Immediately after thawing, the embryos were transferred into PBS containing 1.5 or $2 \mathrm{M}$ glycerol plus $0.5 \mathrm{M}$ sucrose, then moved to PBS containing $0.5 \mathrm{M}$ sucrose at 3 min-intervals at room temperature. At $3 \mathrm{~min}$ later, the embryos were washed twice in fresh PBS. The viability of the frozen-thawed embryos was assessed by their ability to develop to expanded blastocysts during culture for $1 \sim 3$ days. Experiments were replicated $3 \sim 6$ times and the data were analysed for statistical significance using $\chi^{2}$ test. 


\section{Results}

We examined the effects of the exposure time to $2 \mathrm{M}$ glycerol at $0^{\circ} \mathrm{C}$ prior to freezing on the survival of morulae frozen by the methods $\mathrm{E}$ and $\mathrm{F}$. As shown in Table 1, the exposure time of mouse morulae to glycerol was important. When the embryos were frozen without ice-seeding, no embryos survived after freezing following exposure to $2 \mathrm{M}$ glycerol at $0^{\circ} \mathrm{C}$ for $0.1 \mathrm{~min}$ and a low proportion of the embryos $(31 \%)$ was protected following exposure for $1 \mathrm{~min}$. The highest survival rate (55 $61 \%$ ) was obtained when the embryos were exposed to glycerol for $5 \sim 30 \mathrm{~min}(\mathrm{p}<$ 0.01 ) but prolonged exposure $(60 \mathrm{~min})$ appeared to be detrimental. However, if the embryos were frozen by liquid nitrogen vapor after ice-seeding at $-7^{\circ} \mathrm{C}$, a relatively high proportion (60\%) of the embryos was protected after exposure to glycerol for only $0.1 \mathrm{~min}$ (Table 1$)$. The highest survival rate $(73 \sim 82 \%)$ was obtained after exposure to glycerol for $5 \sim 30 \mathrm{~min}(\mathrm{p}<0.05)$ and an exposure for $60 \mathrm{~min}$ again appeared to be detrimental.

When the embryos were frozen by plunging them directly from $0^{\circ} \mathrm{C}$ to a $-40^{\circ} \mathrm{C}$ bath and holding for $10 \mathrm{~min}$ before transfer to liquid nitrogen, embryos did not survive after exposure to $2 \mathrm{M}$ glycerol at $0^{\circ} \mathrm{C}$ for $0.1 \mathrm{~min}$ (Table 2). A $25 \%$ of embryos survived when they were exposed to glycerol for $1 \mathrm{~min}$ and the highest survival rate $(82 \sim 84 \%)$ was obtained after exposure for $20 \sim 30 \mathrm{~min}$.

The results summarized in Table 3 demonstrated that the sensitivity of embryos

Table 1. The effects of equilibration time to $2 \mathrm{M}$ glycerol at $0^{\circ} \mathrm{C}$ prior to freezing on the survival of mouse morulae frozen by placing from 0 or $-7^{\circ} \mathrm{C}$ into liquid nitrogen vapor at $-170 \sim-180^{\circ} \mathrm{C}$ before transfer to liquid nitrogen

\begin{tabular}{|c|c|c|c|c|}
\hline Ice-seeding & $\begin{array}{l}\text { Equilibration time } \\
\text { at } 0^{\circ} \mathrm{C} \\
\qquad(\mathrm{min})\end{array}$ & $\begin{array}{l}\text { No. of } \\
\text { embryos } \\
\text { recovered }\end{array}$ & $\begin{array}{l}\text { No. of } \\
\text { blastocysts } \\
\text { after culture }\end{array}$ & $\%$ Survival \\
\hline \multirow{7}{*}{ Not seeded* } & 0.1 & 55 & 0 & 0 \\
\hline & 1 & 72 & 22 & 31 \\
\hline & 5 & 87 & 53 & 61 \\
\hline & 10 & 68 & 39 & 57 \\
\hline & 20 & 73 & 44 & 60 \\
\hline & 30 & 65 & 36 & 55 \\
\hline & 60 & 67 & 11 & 16 \\
\hline \multirow{5}{*}{ Seeded at $-7^{\circ} \mathrm{C}^{* *}$} & 0.1 & 72 & 43 & 60 \\
\hline & 5 & 67 & 49 & 73 \\
\hline & 10 & 77 & 63 & 82 \\
\hline & 30 & 73 & 55 & 75 \\
\hline & 60 & 60 & 25 & 40 \\
\hline
\end{tabular}

Glycerol was added to embryos at $0^{\circ} \mathrm{C}$ by the single addition. * The morulae were frozen rapidly by placing from $0^{\circ} \mathrm{C}$ into liquid nitrogen vapor at $-170 \sim-180^{\circ} \mathrm{C}$ without ice-seeding and then to liquid nitrogen $15 \mathrm{~min}$ later. ** The morulae were frozen rapidly by placing into liquid nitrogen vapor at $-170 \sim-180^{\circ} \mathrm{C}$ after ice-seeding at $-7^{\circ} \mathrm{C}$ and then to liquid nitrogen 15 min later. 
Table 2. The effects of equilibration time to $2 \mathrm{M}$ glycerol at $0^{\circ} \mathrm{C}$ prior to freezing on the survival of mouse morulae frozen by plunging them directly from $0^{\circ} \mathrm{C}$ into a $-40^{\circ} \mathrm{C}$ bath before transfer to liquid nitrogen

\begin{tabular}{cccc}
\hline \hline $\begin{array}{l}\text { Equilibration time } \\
\text { at } 0^{\circ} \mathrm{C} \\
(\mathrm{min})\end{array}$ & $\begin{array}{l}\text { No. of } \\
\text { embryos } \\
\text { recovered }\end{array}$ & $\begin{array}{l}\text { No. of } \\
\text { blastocysts } \\
\text { after culture }\end{array}$ & \% Survival \\
\hline 0.1 & 53 & 0 & 0 \\
1 & 48 & 12 & 25 \\
5 & 47 & 29 & 62 \\
20 & 51 & 42 & 82 \\
30 & 55 & 46 & 38 \\
60 & 45 & 17 & 84
\end{tabular}

Glycerol was added by the single addition to embryos at $0^{\circ} \mathrm{C}$ and frozen without ice-seeding.

Table 3. Effects of stage of development on the survival of mouse embryos frozen with various methods in the presence of glycerol

\begin{tabular}{llllllll}
\hline \hline & \multicolumn{5}{c}{$\%$ Survival } \\
\cline { 2 - 6 } & Freezing method & 2-cell & 4-cell & 8 -cell & Morula $\begin{array}{l}\text { Early } \\
\text { blastocyst }\end{array}$ & Blastocyst \\
\hline (A) Slow freezing & $0(54)$ & $14(56)$ & $79(66)$ & $88(93)$ & $85(61)$ & $61(63)$ \\
(B) $\begin{array}{l}\text { Slow freezing to }-40^{\circ} \mathrm{C} \\
\text { before transfer to } \\
\text { liquid nitrogen }\end{array}$ & $0(68)$ & $12(51)$ & $85(59)$ & $92(65)$ & $85(55)$ & $48(60)$ \\
(C) $\begin{array}{l}\text { Plunging into a }-20^{\circ} \mathrm{C} \\
\text { bath before transfer } \\
\text { to liquid nitrogen }\end{array}$ & $0(65)$ & $0(49)$ & $56(70)$ & $71(78)$ & $75(51)$ & $39(67)$ \\
(D) Dry ice freezing & $0(51)$ & $5(78)$ & $58(99)$ & $78(88)$ & $80(71)$ & $41(68)$ \\
(E) Liquid nitrogen vapor & $0(50)$ & $0(49)$ & $9(67)$ & $71(65)$ & $68(71)$ & $27(62)$
\end{tabular}

For details of freezing method, see text. Glycerol concentration was $2 \mathrm{M}$ except for method A for which $1.5 \mathrm{M}$ was used. Embryos were frozen after exposure to glycerol at $0^{\circ} \mathrm{C}$ for $10 \mathrm{~min}$. The value in parentheses represents the number of embryos recovered after thawing.

to freezing was largely affected by the embryonic stage of development. The embryos at 2-cell stage did not survive after freezing and a very low proportion $(0 \sim 14 \%)$ of 4-cell stage embryos survived regardless of the freezing methods used. When the embryos were slowly frozen by methods $\mathrm{A}$ and $\mathrm{B}$, the embryos at 8-cell stage, morulae and early blastocysts survived significantly better than 2-cell, 4-cell stage embryos and blastocysts. When rapid freezing methods C, D and E were used, morulae and early blastocysts survived significantly better than 2-cell, 4-cell, 8-cell stage embryos and blastocysts.

\section{Discussion}

Glycerol and DMSO have been the cryoprotective agents used most often for preserving mammalian embryos at low temperatures. However, the exact mechanisms by which their agents protect embryos against freezing damage remain obscure. If protection of embryos requires permeation of the cryoprotective agent into embryos 
and the permeation is time-dependent, the attainment of protection against freezing damage should be time-dependent.

When mouse morulae were rapidly frozen in $2 \mathrm{M}$ glycerol without ice-seeding by placing from $0^{\circ} \mathrm{C}$ to liquid nitrogen vapor before transfer to liquid nitrogen, the survival increased from 0 to $55 \sim 61 \%$ according to the exposure time to glycerol at $0{ }^{\circ} \mathrm{C}$ from $0.1 \mathrm{~min}$ to $5 \sim 30 \mathrm{~min}$. Similarly, if the embryos were rapidly frozen in $2 \mathrm{M}$ glycerol by plunging directly from $0^{\circ} \mathrm{C}$ to a $-40^{\circ} \mathrm{C}$ bath before transfer to liquid nitrogen, the survival rate of morulae increased from 0 to $84 \%$ when exposure to glycerol was increased from 0.1 to $30 \mathrm{~min}$ and a period of $20 \sim 30 \mathrm{~min}$ was necessary to give the highest survival rates. These results suggest that glycerol permeation may be required for protection of embryos against freezing damage, and permeation of glycerol into mouse morulae may enhance their survival. The prolonged exposure ( $60 \mathrm{~min}$ ) to $2 \mathrm{M}$ glycerol at $0^{\circ} \mathrm{C}$ appeared to be detrimental to mouse morulae, probably because of its toxicity at $0^{\circ} \mathrm{C}$.

If the morulae were frozen by liquid nitrogen vapor after ice-seeding at $-7^{\circ} \mathrm{C}$, a relatively high survival was obtained after exposure to glycerol at $0^{\circ} \mathrm{C}$ for $0.1 \mathrm{~min}$. In this case, samples were cooled at $1^{\circ} \mathrm{C} / \mathrm{min}$ to $-7^{\circ} \mathrm{C}$ after the single addition of glycerol at $0^{\circ} \mathrm{C}$, seeded at $-7^{\circ} \mathrm{C}$, and $5 \mathrm{~min}$ later transferred to liquid nitrogen vapor; it took about $12 \mathrm{~min}$ from the addition of glycerol to the transfer of samples into liquid nitrogen vapor. Therefore, it seemed to be reasonable to assume that glycerol entered the embryos before transfer to liquid nitrogen, so that morulae survived after freezing.

The permeability of glycerol to mouse eggs and embryos changes with embryonic stage from the unfertilized egg to the blastocyst stage ${ }^{2-4)}$. Fertilization resulted in an increase in the rate of glycerol permeation of eggs. The embryos at later stages of development were more permeable to glycerol than the embryos at earlier stages; the embryos at 8-cell stage, morulae and blastocysts were much more permeable to glycerol than 1 -cell to 4 -cell stage embryos ${ }^{2-4}$.

In the present study, the survival rates of 8-cell stage embryos, morulae and early blastocysts were higher than those of 2-cell and 4-cell stage embryos, suggesting the embryos at later stages being less susceptible to the present freezing and thawing procedures. In addition to the increase in glycerol permeation of embryos with development, the intracellular concentration of glycerol required for protection at the advanced stages may be reached more quickly because of the reduction in blastomere size with development. JACKOWSKI and LEIBO ${ }^{8)}$ and JACKOWSKI ${ }^{9)}$ found that the variables which increase glycerol permeation of mouse eggs also appear to increase survival after slow freezing. The previous ${ }^{8,9)}$ and present results suggest that increase in glycerol permeation of mouse embryos enhances their survival after slow and rapid freezing, although it is not the sole factor which determines the survival of frozen embryos.

From the photographic study on the volume changes of 8-cell mouse embryos exposed to $1 \mathrm{M}$ DMSO at $0^{\circ} \mathrm{C}$ for various times, LEIBO et al. ${ }^{5)}$ and LEIBO ${ }^{6}$ concluded that 
little DMSO will enter the cells as they are undergoing osmotic dehydration and DMSO need not permeate 8-cell mouse embryos to protect them against freezing damage. He proposed that one cause of freezing damage is the total extent and the rate at which a cell is required to undergo shrinkage resulting from osmotic dehydration at subzero temperatures and the cell membrane is unable to tolerate extensive shrinkage ${ }^{6}$. A cryoprotective agent such as glycerol or DMSO may protect a cell by reducing the total extent to which the cell must shrink during freezing, either by causing it to shrink prior to freezing, or by entering the cell and thereby decreasing the extent of shrinkage during freezing ${ }^{6}$. Further experiments are needed to understand the exact mechanisms by which the cryoprotective agents protect embryos against the injurious effects of low temperatures.

In the present study, the survival rate of blastocysts was lower than that of morulae and early blastocysts. The blastocyst and early blastocyst possess a fluid-filled blastocoelic cavity and the range of volume variations depends on the degree of expansion of the blastocyst. Since the intracellular ice damages the cells and impairs embryo survival, blastocysts that contain much water in their blastocoel, where the dehydration of the blastocoel may not be completed during freezing, survived poorly whereas morulae and early blastocysts that contain less water survived better ${ }^{10}$. This may be an explanation for the difference in survival rate observed between blastocysts, and morulae and early blastocysts in our experiments.

\section{Acknowledgements}

This work was supported in part by a grant-in-aid for scientific research from the Ministry of Education, Science and Culture, Japan.

\section{References}

1) Whittingham, D. G., in Low Temperature Preservation in Medicine and Biology (AshwoodSmith, M. J. and J. Farrant, eds. ) 65-83. Pitman Medical. Kent. 1980.

2) Jackowski, S., S. P. Leibo and P. Mazur, J. Exp. Zool., 212: 329-341. 1980.

3) Mazur, P., N. Rigopoulos, S. C. Jackowski and S. P. Leibo, Biophys. J., 16: 232 a. 1976.

4) Leibo, S.P., in The Freezing of Mammalian Embryos (Elliott, K. and J. Whelan, eds.) 69-96. Elsevier. Amsterdam. 1977.

5) Leibo, S. P., P. Mazur and S.C. JACкоwsk1, Exp. Cell Res., 89: 79-88. 1974.

6) Leibo, S. P., in Basic Aspects of Freeze Preservation of Mouse Strains (Müнвоск, O., ed.) 13-33. Gustav Fischer Verlag. Stuttgart. 1976.

7) Whittingham, D. G., Nature 233: 125-126. 1971.

8) JАCкош'sк1, S. and S.P. Leibo, Cryobiology 13: 646. 1976.

9) Jackowski, S. Ph. D. Dissertation, University of Tennessee. 1977. Cited S. P. from Le1bo, and P. Mazur., in Methods in Mammalian Reproduction (Daniel, J.C. Jr. ed.) 179-201. Academic Press. New York. 1978.

10) Massip, A., P. V.D. Zwalmen and F. Leroy, Cryobiology 21: 574-577. 1984. 
マウス胚の凍結におけるグリセリン平衡時間の重要性

宮本 元・宮本庸平・石橋武彦

京都大学農学部, 京都市 606

哺乳類胚の凍結保存において, 胚を凍書から保護する には，添加された保讙物貿が服に透過する必要があるか 否かについてはいまだ明らかでない、タリセりン平衡時 間怙よび㗏の発生段階か，凍結・融解マウス胚の生存性 に及ぼす影響を明らかにするために本実験を行なった。 種々の方法で東結した胚を $40^{\circ} \mathrm{C} の$ 温水中で振とうしな がら急速融解し，培涹によって增大した胚盤胞に発生し

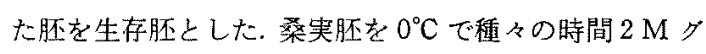
リセリンに平衡させた後, 植办せずに $0^{\circ} \mathrm{C}$ から淔接 -170 $\sim-180^{\circ} \mathrm{C}$ の夜体窒素ガス内に移し，15 分後に液体窒素 八餵漬した. 0.1 分のグリ七りン平衡後,胚は倲結によっ て死隇したが，1分の平衡では 31\%の胚が生存し，5～

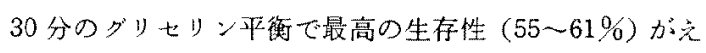
られた。これに対して， $-7^{\circ} \mathrm{C}$ で植水しその5 分娞に液 体壆素ガス内に移して倲結すると，0.1分のタリ七りン 平衡後で 60\%の胚が生存し，5３0分のダリセリン平衡 のときに最高の生存性 $(73 \sim 82 \%)$ がえられた。この場

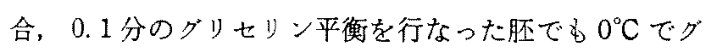

リ七リンを添加してから液体空素ガス内一移すまで約 12 分間経過しているのでこの間にグリセりンが細胞内に 透過した可能性がある. 桑実胚を植水せずに $0^{\circ} \mathrm{C}$ から直

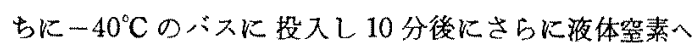
浸漬すると, 0.1 分のグリ七リン平衡では肧は死滅し, 20〜30分のグリセリン平衡で最高の生存性（82〜84\%） がえられた２細胞胚から脴盤胞までの種々の発生段階 の胚を、グリ七りンの存在下で凍結した，胚を緩僈凍結 法で涷結すると，グリセリンの透過性が高いといわれる 8 細胞胚，桑実胚および初期脴桖胞は 2 細胞胚， 4 細胞 胚扎よび脴艋胞より生存性が嵪く，二段階凍結法で涷結 すると桑実胚と初期胚盤胞は他の発生段階の㗏上り生存 性が高かった。これらの成樍から，マウス脴を凍害から 保護するには，グリセリンが胚内に透過することが必要 でありグリセりンの透過が增せば肧の生存性が高をる と思われる。

日畜会報，57 (3)：250-256，1986 